\title{
ОЦЕНКА ДЕЯТЕЛЬНОСТИ РУКОВОДИТЕЛЕЙ ОРГАНИЗАЦИИ НА ОСНОВАНИИ КОМПЕТЕНТНОСТНО-ОРИЕНТИРОВАННОЙ МОДЕЛИ
}

\author{
Янцен Константин Иванович 1 , \\ yanzen14@gmail.com \\ Мещерякова Эмма Ивановна 1 , \\ mei22@mail.ru. \\ Ларионова Анастасия Вячеславовна1, \\ vktusur@mail.ru \\ ${ }^{1}$ Национальный исследовательский Томский государственный университет, \\ Россия, 634050, г. Томск, пр. Ленина, 36.
}

\begin{abstract}
Янцен Константин Иванович, кандидат психологических наук, доцент кафедры организационного поведения и управления персоналом Института экономики и менеджмента Национального исследовательского Томского государственного университета.
\end{abstract}

Мещерякова Эмма Ивановна, доктор психологических наук, профессор, профессор кафедры генетической и клинической психологии факультета психологии Национального исследовательского Томского государственного университета.

Ларионова Анастасия Вячеславовна, кандидат психологических наук, доцент кафедры генетической и клинической психологии факультета психологии Национального исследовательского Томского государственного университета.

Актуальность исследования определяется необходимостью развития кадрового потенциала финансовых организаций в условиях нестабильной социально-экономической ситуации в мире, которая выдвигает повышенные требования к профессиональной компетентности руководителей организаций. Предметом исследования является система оценки компетенций руководителей организации. Объектом исследования выступает компетентностно-ориентированная модель руководителя. Авторы на основе модели Great Place to Work рассматривают опыт внедрения компетенций в систему управления персоналом организации, необходимых для достижения корпоративных, профессиональных, универсальных целей организации. Цель исследования заключалась в изучении эффективности функционирования представленной модели компетенций в профессиональной деятельности руководителей Томского отделения ведущего банка России, что позволило выявить зоны роста сотрудников, подобрать программы их обучения, усовершенствовать систему управления коллективом и получить обратную связь. В качестве основного метода исследования использовался метод «360 градусов», позволяющий получать информацию о действиях работника в реальных рабочих ситуациях и проявляемых им личностных и деловых качеств - компетенций. Представленная модель компетенций может использоваться для системы управления персоналом банка с целью максимально полного и эффективного использования профессионального потенциала его сотрудников. Оценка на основе компетенций открывает ряд перспектив для компании: возможность разработать единые стандарты эффективности профессиональной деятельности, определить слабые и сильные стороны каждого сотрудника и использовать эту информацию для его развития. Приведены основные показатели, характеризующие состояние и уровень развития компетенций руководителей Томского отделения ведущего банка России. Представлена модель компетенций как надежная основа для эффективного управления персоналом банка, а также способ оценки модели с помощью метода «360 градусов».

Ключевые слова: Банк, менеджмент, организация, компетенции, руководство, персонал, метод «360 градусов». 
Совершенствование системы управления персоналом на предприятии является ключевым фактором роста эффективности деятельности любой компании. В связи с этим возрастает роль развития кадрового потенциала компании. Быстрое развитие банковских технологий приводит к необходимости оценки уровня знаний, умений, навыков работников, чтобы спрогнозировать возможности их использования с учетом организационных перспектив банка. Одной из проблем управления является отсутствие системности в требованиях к руководящему персоналу. Как правило, основными требованиями к работнику являются профессиональные компетенции, а личностные качества считаются пока что маловажными, вторичными [1]. Становление организационной психологии и HR-менеджмента в России находится в самом начале своего развития, что обуславливает потребность в научных исследованиях и внедрениях различных практик [2].

Одной из наиболее интересных и продуктивных теоретико-методологических основ интеграции системы управления персоналом организации является компетентностный подход, предполагающий выделение так называемых компетенций работников с последующим объединением их в модели компетенций. Что касается понятий «компетентность» и «компетентностный подход», то они наиболее репрезентативно рассмотрены в современной отечественной науке А.В. Хуторским, Э.Ф. Зеером, Н.Л. Гончаровой, И.А. Зимней, А.М. Дохоян и др. [3-7]. В.И. Байденко и Б. Оскарссон [8] характеризуют компетентность как «динамичную совокупность знаний, умений, навыков, способностей, необходимую для эффективной профессиональной и социальной деятельности и развития личности выпускников, которую они обязаны освоить и продемонстрировать после завершения части или всей образовательной программы» [9].

Компетентностный подход активно внедряется в практику крупнейших коммерческих банков РФ, так как руководство финансовых организаций осознает значимость эффективной деятельности персонала [9]. Под компетенцией понимается «совокупность взаимосвязанных качеств, задаваемых по отношению к определенному кругу предметов и процессов, необходимых, чтобы качественно и продуктивно действовать по отношению к ним». Автор подчеркивает необходимость разделять содержание понятий «компетенция» и «компетентность», имея в виду под компетенцией заранее заданное требование к образовательной подготовке человека, а под компетентностью уже состоявшееся личностное качество (совокупность качеств) ученика и минимальный опыт деятельности в заданной сфере [9].

С точки зрения бизнес-практиков, корпоративные компетенции представляют собой объем профессиональных навыков и знаний, личностные установки и характеристики, которые проявляются в поведении сотрудников, требуют выполнения некоторых должностных обязанностей. Модель компетенций - совокупность определенных компетенций, которые нужны сотрудникам для достижения целей, поставленных руководством компании. Только при наличии у работников определенных навыков можно рассчитывать на успешное развитие организации. Всестороннее исследование сущности феномена «компетентность» в корреляции с формированием профессиональной готовности специалиста проведено в работах И.А. Зимней (2003) [6]. Корпоративные компетенции предполагают систему навыков и умений, которыми обладает работник, для того чтобы успешно реализоваться в профессиональной сфере профессиональные компетенции - это способность субъекта профессиональной деятельности выполнять работу в соответствии с должностными требованиями [10]. Последние представляют собой задачи и стандарты их выполнения, принятые в организации или отрасли [11]. Служба человеческих ресурсов играет ключевую роль в управлении современ- 
ной организацией, поэтому ее сотрудники должны обладать критическими для этого процесса навыками: определять направление развития организации, формулировать цели, вырабатывать методы достижения этих целей и внедрять их в организацию, эффективно преодолевать сопротивление переменам. Для этого специалистам по персоналу нужны профессиональные знания в области планирования, разработки и анализа альтернативных стратегий, принятия решений, эффективной коммуникации, создания рабочих групп, мотивирования сотрудников, разрешения конфликтов.

Данная точка зрения весьма созвучна с позицией представителей британской школы психологии труда, в основном придерживающихся функционального подхода, согласно которому под профессиональными компетенциями понимается способность действовать в соответствии со стандартами выполнения работы. Данный подход сфокусирован не на личностных характеристиках, а на стандартах деятельности и основан на описании задач и ожидаемых результатов. В работах британских специалистов можно найти множество схожих определений профессиональной компетенции: способности; адекватные или достаточные физические или интеллектуальные качества; способность быть квалифицированным; способность делать что-либо хорошо или в соответствии со стандартом, приобретенная опытным путем или в результате обучения; способность выполнять определенную роль, охватывающее знания, способности, поведение.

Американские специалисты в сфере психологии труда, как правило, являются сторонниками «личностного» подхода - они ставят во главу угла характеристики личности, позволяющие ей добиваться результатов в работе [12]. Они традиционно ограничивают объем понятия профессиональной компетенции либо качествами личности, либо знаниями, умениями, способностями, и используют аббревиатуру KSAO: знания (knowledge); умения (skills); способности (abilities); иные характеристики (other). В американской практике склонны интерпретировать профессиональную компетенцию как важный поведенческий аспект.

Внедрение модели компетенций в систему управления персоналом организации предполагает в первую очередь точное определение компетенций, необходимых для достижения целей организации. В различных организациях модели компетенций отличаются, но среди них можно выделить общие и выяснить их пригодность для конкретной отрасли. Кроме того, если говорить о банковской отрасли, можно отметить, что лишь немногие банки уже внедрили в практику работы с персоналом использование компетенций. В исследуемом банке была внедрена модель Great Place to Work, paзработанная Майкл Берчелл и Дженнифер Робин в компании PricewaterhouseCoopers [13]. PricewaterhouseCoopers (PwC) - международная сеть компаний, предлагающих профессиональные услуги в области консалтинга и аудита. Компания существует на протяжении более 160 лет и входит в так называемую большую четвёрку аудиторских компаний и 100 лучших работодателей США. В рамках программы партнерского охвата (англ. Partner Connectivity) партнеры компании, начиная со старших, берут шефство над 15 сотрудниками компании. Их задача - наладить профессиональный и личный контакт, познакомиться с семьями, выяснить, чем интересуются и к чему стремятся сотрудники. Сотрудник раз в квартал встречается со своим наставником, чтобы обсудить свои сильные и слабые стороны и способы усиления первых и коррекции вторых. Подобная гуманистическая направленность менеджмента выглядит достаточно обоснованно и привлекательно.

В предварительном исследовании с помощью модели Great Place to Work среди основных корпоративных компетенций сотрудников банка были выделены компетенции, представленные в табл. 1. 
Таблища 1. Модель компетенций сотрудников ведущего банка России

Table 1. Competence model for employees of the leading bank of Russia

\begin{tabular}{|c|c|c|}
\hline \multicolumn{3}{|c|}{ Компетенции/Competencies } \\
\hline $\begin{array}{c}\text { Корпоративные (для банка) } \\
\text { Corporate (for bank) }\end{array}$ & $\begin{array}{l}\text { Профессиональные (для начальни- } \\
\text { ков отделов) } \\
\text { Professional (for department heads) }\end{array}$ & $\begin{array}{c}\text { Универсальные (личностные) } \\
\text { Universal (personal) }\end{array}$ \\
\hline $\begin{array}{c}\text { Управление клиенто- } \\
\text { ориентированностью } \\
\text { Customer Orientation Manage- } \\
\text { ment }\end{array}$ & $\begin{array}{c}\text { Управленческая ответственность } \\
\text { Managerial responsibility }\end{array}$ & $\begin{array}{c}\text { Системность и гибкость мышле- } \\
\text { ния } \\
\text { Systematic and flexible thinking }\end{array}$ \\
\hline $\begin{array}{c}\text { Предпринимательские способ- } \\
\text { ности } \\
\text { Entrepreneurial skills }\end{array}$ & $\begin{array}{c}\text { Лидерство и организаторские спо- } \\
\text { собности } \\
\text { Leadership and Organizational Abili- } \\
\text { ties }\end{array}$ & $\begin{array}{c}\text { Способность работать в команде } \\
\text { Ability to work in a team }\end{array}$ \\
\hline $\begin{array}{c}\text { Корпоративная лояльность } \\
\text { Corporate loyalty }\end{array}$ & $\begin{array}{l}\text { Профессиональное саморазвитие } \\
\text { Professional self-development }\end{array}$ & $\begin{array}{l}\text { Коммуникативная компетент- } \\
\text { ность Communicative competence }\end{array}$ \\
\hline
\end{tabular}

В табл. 1 указывают группы и подгруппы выделенных компетенций, содержание которых раскрывается ниже.

Корпоративные (для банка) компетенции составляют: Управление клиентоориентированностью, Предпринимательские способности, Корпоративная лояльность.

Клиентоориентированность предполагает три уровня выражения: внешний и внутренний для сотрудников, а также дополнительный уровень для топ-менеджмента. Клиентоориентированность организации становится одним из основных факторов ее конкурентоспособности. Для создания конкурентных преимуществ в настоящее время важно устанавливать и поддерживать долгосрочные отношения как с внешними, так и с внутренними клиентами. Особую роль в достижении данной цели играет персонал организации, так как именно он взаимодействует с клиентами. Появление новых требований к персоналу и к построению работы с ним в соответствии с клиентоориентированным подходом демонстрирует эволюционную тенденцию обогащения управления персоналом как теоретической области знаний, так и направления практической деятельности [14].

Предпринимательские способности и предпринимательская компетентность - совокупность личных и деловых качеств, навыков, знаний, определенного рода модель поведения, владение которыми помогает успешно решать различные бизнес-задачи и достигать высоких результатов деятельности. В.С. Морозовой (2012) выделены основные аспекты структуры предпринимательской компетентности: личностный, организационный, коммуникативный, инновационный [15]. Интеллектуальная деятельность, специальные знания и бизнес-коммуникации стали основными факторами конкурентоспособности отделений и филиалов банка, как и инновации в области планирования и управления, в сфере инфраструктурных процессов - логистики, маркетинга и обслуживания. В целом речь идет о стратегии инновационного менеджмента, иначе - о стратегическом аспекте управленческих инноваций $[16,17]$.

Корпоративная лояльность. По Андрющенко О.В. (2011), лояльность в организации понимается в широком смысле - установочно-поведенческий комплекс, внешним выражением которого является участие акторов в деятельности организации, соответ- 
ствующее ее требованиям [18]. В процессе борьбы за лояльность персонала становится ясно, что в основе успеха лежат взаимовыгодные отношения [19]. Сотрудники должны быть уверены, что их лояльность будет по достоинству оценена сверху. Иными словами, достаток, социальная защита и карьерные перспективы персонала должны быть адекватны уровню его ответственности и уважения к фирме. Для диагностики отношения сотрудников к политике компании и ее руководству в большинстве компаний используют опросы и анкетирование (как правило, анонимные), предлагают вносить предложения.

Профессиональные (для начальников отделов банка) компетенции составляют: Управленческая ответственность, Лидерство и организаторские способности, Профессиональное саморазвитие.

Управленческая ответственность - это необходимость давать отчет за решения и действия менеджера, а также и за их последствия. Выделяют общую управленческую ответственность, которую несет руководитель за создание необходимых условий работы, и функциональную ответственность исполнителя за конкретный результат. Если полномочия превосходят ответственность, велика опасность административного произвола. Ситуация «полномочия меньше ответственности» влечет паралич управленческой деятельности. Если полномочия соответствуют ответственности, работа идет нормально. Почему необходимо распределение управленческих полномочий? Рост масштабов производства приводит к невозможности управлять в одиночку. Руководителю организации приходится идти на расщепление управленческих полномочий. Это означает распределение полномочий среди подчиненных сверху вниз. Количественными характеристиками имеющихся у менеджера управленческих полномочий являются объемы ресурсов, которыми он может распоряжаться без согласования с вышестоящей инстанцией, и число лиц, прямо или косвенно обязанных следовать принятым им решениям. Исследователи выделяют факторы, определяющие масштабы полномочий на том или ином уровне управления. Масштабы полномочий, сосредоточенных у одного субъекта, зависят от сложности, важности, разнообразия решаемых проблем, динамики бизнеса и размеров организации [20].

Лидерство и организаторские способности. Цель руководителя - эффективное управление ресурсами компании для достижения целей, стоящих перед организацией. Для эффективного управления необходим успешный лидер в лице руководителя с определенным набором компетенций. Лидерские компетенции - это личностные характеристики, проявляющиеся в поведении человека. К таким можно отнести: стрессоустойчивость, умение вдохновлять, стремление развиваться как в личном, так и в профессиональном плане, уверенность, организаторские способности и т. д. Реалии современного мира таковы, что не каждый руководитель является лидером, и наоборот: не каждый лидер - руководитель. Руководитель - это «лицо, официально наделенное правом принимать и реализовывать управленческие решения в организации. Лидер - это лицо в неформальной или формальной организации, обладающее влиянием, необходим для реализации принимаемых им решений» [21].

Профессиональное саморазвитие - эта компетенция профессионального саморазвития рассматривается как способность человека реализовать на практике свой субъектный опыт в области профессионального самоопределения и самореализации на основе осознанной саморегуляции своей профессиональной деятельности [22]. Проблема профессионального саморазвития представлена широким спектром разновекторных исследований и имеет большое значение, так как практическая деятельность в современных условиях предъявляет специфические требования к профессионалу. От него 
требуется не только воспроизведение полученных знаний, но и творческий подход к решению профессиональных задач, способность к постоянному самообразованию, личностному и профессиональному самосовершенствованию.

Универсальные (личностные) компетенции определяются через Cистемность $u$ гибкость мышления, Способность работать в команде, Коммуникативную компетентность.

Системность и гибкость мылиения. Большинство определений характеризуют системное мышление как эффективный способ познания, особенно выделяя его прогностические преимущества и специфику целостного, динамического восприятия. Эта компетенция находит свое отражение в трех формах: аналитическом, системном и стратегическом мышлении [23]. Их значимость варьируется в зависимости от категории работника. Эффективность системного мышления в познавательной деятельности обусловлена тем, что все окружающие нас системы, с точки зрения системного подхода, обладают схожими свойствами, например, петли обратных связей, ортогональность и жизненный цикл $[24,25]$.

Способность работать в команде как компетенция рассматривается психологами как владение, обладание человеком соответствующей компетенцией, включающей его личностное отношение к ней и предмету деятельности. Организации, руководство которых занимается командной работой, работой по сплочению коллектива, мотивацией сотрудников, формированием благоприятного психологического климата, на сегодняшний день на рынке услуг являются более успешными по сравнению с теми, которые такую работу не проводят.

Коммуникативная компетентность выступает в контексте формирования широкого репертуара социальных компетенций. Определение коммуникативной компетентности осуществляется, во-первых, через психологическое понятие личностной готовности, во-вторых, - готовность и умение использовать ресурсы именно для организации и осуществления коммуникативных действий - речь идет о необходимости самоорганизации и субъектности личности, что становится значимым именно в нелинейной социальной системе. Коммуникативная компетентность, являясь неотъемлемой частью коммуникативной культуры, необходима всем без исключения людям, а в ряде профессий она становится профессионально значимой характеристикой личности $[26,27]$. В настоящее время в психологии недостаточно разработана проблема становления коммуникативной компетентности профессионала. В большей степени изучены отдельные компоненты, а не данный феномен в целом. Но рядом исследователей отмечается, что развитое внимание к другому человеку, умение понимать и принимать другого человека, душевная чувствительность, умение понимать и управлять ситуациями общения - основа коммуникативной компетентности и в организации, и в жизни.

С целью изучения эффективности функционирования представленной модели компетенций в профессиональной деятельности руководителей Томского отделения банка было организовано и проведено представленное исследование. Результаты проведения исследования позволили выявить зоны роста сотрудников, подобрать программы их обучения, усовершенствовать систему управления коллективом и получить обратную связь.

Выборка, методы и процедура исследования. Исследование проходило на базе Томского отделения ведущего банка России. В исследовании приняло участие 96 служащих, чьей задачей было оценить 31 руководителя. Данные собирались с помощью анкетного опроса. Анкета состояла из 45 вопросов, сгруппированных в три типа вышеописанных компетенций (корпоративные, профессиональные, личностные). Использо- 
вался метод «360 градусов», позволяющий получение информации о действиях работника в реальных рабочих ситуациях и проявляемых им личностных и деловых качеств - компетенций [28]. В зависимости от спектра решаемых задач организационное исследование на основе методики «360 градусов» можно комбинировать с другими инструментами оценки: профессиональные тесты, ассессмент-центр, наблюдение, интервью, социометрия и пр.

Оценка персонала данным методом подойдет далеко не всем компаниям. Если в организации доминирует авторитарный стиль управления, нет традиции групповых методов работы, наблюдается дистанцирование руководства от коллектива, преобладает жесткий контроль и систематически применяются организационные наказания, то от использования «360 градусов» лучше отказаться. А вот компаниям с «демократичной корпоративной культурой», в том числе там, где наблюдается доверие к HR-службе и руководству, метод может быть весьма эффективным. Оценка ведется по списку компетенций, предъявляемых к должности оцениваемого. Одним из существенных плюсов методики является её адаптируемость под конкретную компанию с учетом целей и задачей должностей организации, корпоративных ценностей. Суть данного подхода заключается в том, что личные и профессиональные качества сотрудника оцениваются по результатам анализа полученных мнений людей, непосредственно взаимодействующих при работе с оцениваемым сотрудником. Согласно принципам, заложенным в проведении оценки, сотрудники организации оказывают существенную помощь коллеге в понимании его сильных и слабых сторон, в планировании дальнейшего развития и роста. Для каждого оцениваемого руководителя выбираются от 7 до 9 оценщиков-экспертов, которые хорошо знают оцениваемого по их совместной деятельности. В состав экспертов включаются: руководитель оцениваемого сотрудника, коллега, равный по статусу оцениваемому, подчиненный, внутренний клиент смежной службы и сам оцениваемый сотрудник. Далее сотрудникам-участникам по электронной почте отправлялась анкета для заполнения, где было необходимо оценить компетенции руководителя по пяти уровням оценки: «недостаточный уровень», «ниже среднего», «средний уровень», «выше среднего», «высокий уровень».

\section{Результаты исследования}

Был проведен дисперсионный анализ выборки, позволяющий увидеть, как разные категории экспертов оценили руководителей банка по каждой из компетенций (рис. 1).

На диаграмме (рис. 1) видно, что работник оценивает себя на том же уровне, что и его руководитель и внутренние клиенты. При этом коллеги и подчиненные оценивают работника выше, чем его самооценка и оценки руководителя и клиентов. Это может свидетельствовать о двух взаимоисключающих тенденциях: или была не проработана анонимность исследования, или данные свидетельствуют о существующей в организации обстановке доверия к руководителям, уважении к ним и к их стилю управленческой деятельности.

Далее были проанализированы усредненные общие оценки компетенций руководителя (рис. 2).

Как видно из рис. 2, стоит заметить и учитывать, что максимальный средний балл оценки компетенций равен примерно 3,75 балла из возможных пяти баллов. Другими словами, практически все оценки варьируются в диапазоне от 3,5 до 3,8 (чуть выше среднего уровня). Крайние оценки не наблюдаются. Анализ рисунка показывает, что для руководителей наиболее свойственны корпоративные и профессиональные компетенции. 


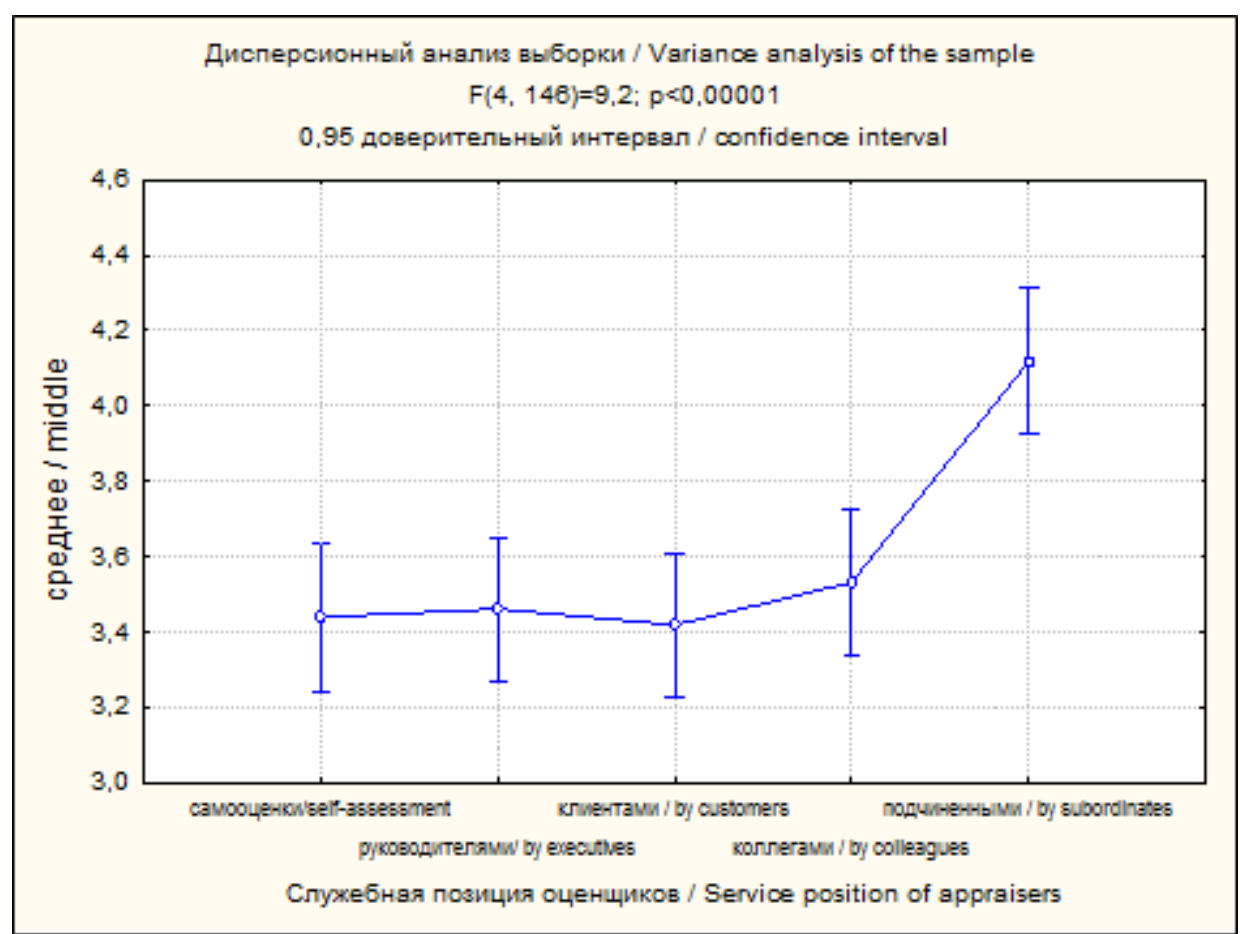

Pис. 1. Общегрупповая разнища в оценках разными сотрудниками (146 итоговых средних оценок)

Fig. 1. Assessement of overall group difference in estimates by different evaluators (146 total average estimates)

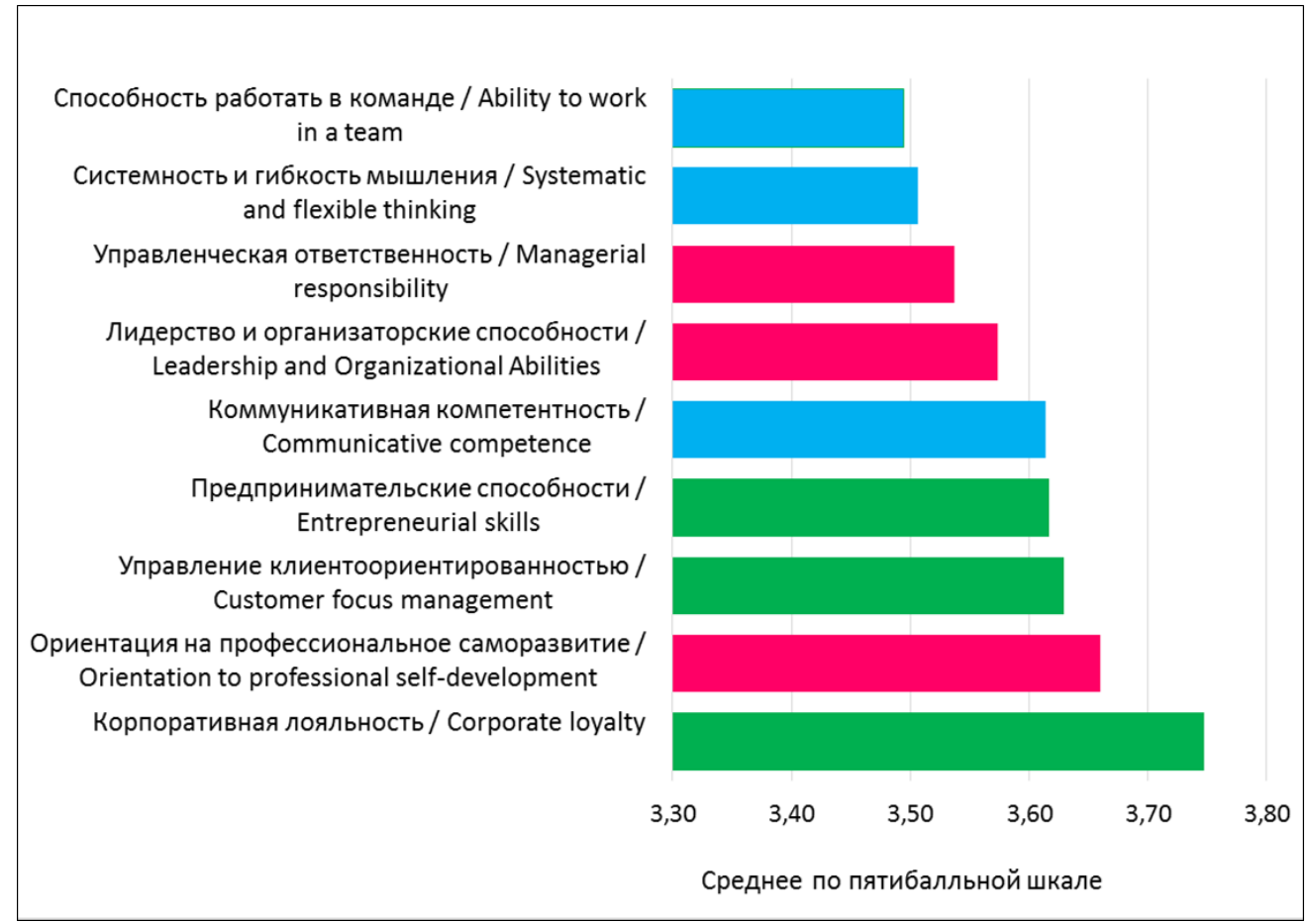

Puc. 2. Оценка общегрупповой развитости компетенций в выборке начальников отделов банка (31 человек)

Fig. 2. Evaluation of the group-wide development of competencies in the sample of heads of departments of the bank (31 people) 
Первыми в списке корпоративных компетенций оказываются корпоративная лояльность и ориентация на профессиональное саморазвитие. Что касается корпоративной лояльности, то анализ показывает, что оценщики отмечают в руководителях приверженность компании, гордость за нее, желание быть частью команды, достигать целей, стоящих перед компанией, развиваться вместе с ее ростом. Они отождествляют себя с компанией, принимают ее на всех уровнях, разделяют ее ценности, миссию, корпоративную культуру. Они способны идти на компромиссы, иногда в ущерб своим личным целям. Высокий уровень лояльности определяется низким уровнем текучести кадров и устойчивым психологическим климатом в коллективе. Что касается компетенции ориентации на профессиональное саморазвитие, то это определяется оценщиками через наличие у руководителей рефлексивных способностей, непрерывный рост и самосовершенствование, в работе над собой в интеллектуальном, культурном, философском, эстетическом, духовном направлениях.

Наименьшие оценки получают такие компетенции, как работа в команде, системность и гибкость мышления. Что касается компетенции работы в команде, то эта наиважнейшая компетенция коллективной деятельности в организации. Способность руководителя сформировать единую, слаженную команду позволяет ему создать крепкий каркас компании. Основополагающая компетенция руководителя - умение и желание работать в команде, применяя эффективные механизмы мотивации, систему поощрений и внутреннего контроля. Грамотный управленец является авторитетом, примером для подражания сотрудников. Он формирует правила, устанавливает режим и сам беспристрастно следует ему, создает благоприятную атмосферу в команде, а также комфортные условия для работы и умеет влиять на социально-психологический климат в коллективе [29-31].

И если оценщики дают этой компетенции наименьший балл, то это свидетельствует о том, что при умении создать командный дух в коллективе, привлечь всех членов организации к формулированию командной цели, создать атмосферу творчества и инициативы, выступать в роли наставников для других, являться неформальными лидерами, обладать заслуженным авторитетом, устанавливать эффективные связи со всеми подразделениями компании и эффективные правила коммуникации, руководители при этом неубедительно приводят ключевые аргументы при взаимодействии, недостаточно эффективно ведут переговоры, не всегда могут влиять на принятие решений, не запрашивает обратную связь о качестве взаимодействия, иногда не имеют представления о том, как достичь успеха в изменении точек зрения и поведения других людей. Эффективный управленец знает сильные и слабые стороны каждого сотрудника, анализирует их способности и учитывает при расстановке кадров в выполнении приоритетных и второстепенных задач. Хороший руководитель понимает важность квалификационного роста для персонала, поэтому своевременно внедряет систему обучения кадров с учетом приоритетных зон развития.

Что касается отмеченной невысокой компетенции системности и гибкости мышления - важной компетенции коллективной деятельности в организации, - то при способности структурировать подход к решению различных задач организации и их систематизировать их, определять их приоритетность и важность оценщики отмечают неспособность структурировать большой объем задач, распределить их по степени срочности и важности. Также отсутствуют некоторые навыки планирования и управления. Эта компетенция руководителя ценится сегодня, как никогда. Умение общаться, способность правильно «подать» себя, присутствующий дар убеждения и точность выражения мыслей - ключевые компетенции руководителя в любой сфере бизнеса. Для того 
чтобы убеждать «массы», эффективно вести переговоры внутри компании и вне ее, необходима немалая гибкость ума. Чтобы грамотно проводить собрания, удерживать внимание аудитории и уверенно вести группу в нужном направлении, необходимо вырабатывать умение преподнести информацию, а также практиковать навыки управления эмоциями и быстро анализировать ситуацию. Системность и гибкость мышления проявляется в нестандартном подходе к решению задач, склонности к декомпозиции, прогнозированию. Руководитель способен быстро ориентироваться и приспосабливаться к изменяющейся ситуации, внедрять новые методики, подходы, генерировать интересные, новаторские идеи. Такой руководитель тщательно формирует свою картину мира, находит в ней изъяны и неточности, признает их и даже больше - использует как «трамплин» для роста управленческих компетенций. Он умело применяет и дозирует контроль, опирается на выстроенную систему контроля и координирования. Способен мыслить глобально, быть дальновидным и видеть перспективы - именно это помогает ему планировать ключевые задачи и направлять деятельность компании в нужном русле. Аналитический подход к этой компетенции требует рассмотрения системного мышления на уровне «восприятие системы», где оно на первом уровне выступает в роли познавательной функции и строится преимущественно на индивидуальных познавательных способностях. Второй уровень, «описание системы», начинает требовать от пользователя наличие знаний техник системного мышления для более глубокого анализа или наличие опыта решения конкретных задач. Решение на этом уровне идет благодаря визуализации системы, в которой поставлена задача, так как правильное построение схемы делает многие решения очевидными, что зачастую подходит в простых задачах. Третий уровень - «управление системой» - требует специальных профессиональных знаний, связанных с областью, в которой применяется системное мышление.

На основании полученных результатов изучения эффективности функционирования представленной модели компетенций в профессиональной деятельности руководителей Томского отделения банка были выявлены зоны роста сотрудников, осуществлен подбор программ корпоративного обучения, усовершенствованы методы управления коллективом организации в плане учета осуществления ее жизненных циклов и работы с потребителем $[14,32]$. Это является необходимым в эпоху появления нового типа менеджмента - креативного менеджмента, креативно-инновационной парадигмы управления, активно использующей технологии творчества и новаторства в отношении всех сфер организационной деятельности, постоянного притока новых идей, предложений, изобретений; ускорения рыночной реализации новшеств, поиска новых форм хозяйствования.

\section{Выводы по результатам исследования}

1. Максимальный средний балл оценки компетенции равен примерно 3,75 балла из возможных пяти баллов. Другими словами, практически все оценки варьируются в диапазоне от 3,5 до 3,8 (чуть выше среднего уровня), т. е. наблюдается умеренность в оценивании руководящего состава. Оценки коллег и подчиненных намного выше самооценки и оценки руководителя. Сотрудники оценивают себя на том же уровне, что и его руководитель. Для руководителя наиболее свойственны корпоративные и профессиональные компетенции. Компетенция инновационности является для работников всех отделений ведущего банка России уже отработанной взаимосвязанной со всеми вышеперечисленными компетенциями и пронизывающей их. Универсальные компетенции остаются второстепенными, но обязательными для руководящей деятельности. 
2. Оценка на основе компетенций открывает ряд перспектив для компании: возможность разработать единые стандарты эффективности работы, определить слабые и сильные стороны каждого работника и использовать эту информацию для его развития.

3. Представленный практический опыт оценки компетенций отражает современное положение развития персонала, приоритеты в развитии компетенций управленцев.

4. Модель компетенций является надежной основой для эффективного построения всей системы управления персоналом банка с целью максимально полного и эффективного использования профессионального потенциала его сотрудников и может применяться в системе управления персоналом не только каждого банка, но и каждой организации.

\section{СПИСОК ЛИТЕРАТУРЫ}

1. Спенсер-мл. Л.М., Спенсер С.М. Компетенции на работе. Модели максимальной эффективности работы; пер. с англ. - М.: НIPРО, 2005. - 384 с.

2. Шинкевич O.K. Основы менеджмента: курс лекций. URL: http://uchebnikonline.com/soderzhanie/textbook_199.html (дата обращения 20.02.2018).

3. Хуторской A.В. Ключевые компетенции и образовательные стандарты // Эйдос. URL: http://www.eidos. ru/journal/2002/0423.htm (дата обращения 20.02.2019).

4. Зеер Э.Ф. Психология профессий. - М.: Академический Проект; Екатеринбург: Деловая книга, 2003. $-336 \mathrm{c}$.

5. Гончарова Н.Л. Категория «компетентность» и «компетенция» в современной образовательной парадигме // Сборник научных трудов СевКавГТУ. Серия «Гуманитарные науки». - 2007. - № 5. C. $13-16$.

6. Зимняя И.А. Ключевые компетенции - новая парадигма результата образования // Высшее образование сегодня. -2003 . - № 5. - С. 34-42.

7. Дохоян А.М. К вопросу о «компетенции» и «компетентности» // Научно-методический электронный журнал «Концепт». - 2015. - Т. 26. - C. 11-15. URL: http://e-koncept.ru/2015/95287.htm (дата обращения 20.02.2019).

8. Байденко В.И., Оскарссон Б. Базовые навыки (ключевые компетенции) как интегрирующий фактор образовательного процесса // Профессиональное образование и формирование личности специалиста. URL: https://cyberleninka.ru/article/n/kompetentsii-v-professionalnom-obrazovanii-k-osvoeniyukompetentnostnogo-podhoda (дата обращения 20.02.2019).

9. Долженко Р.А. Компетентностный подход как основа системы управления персоналом в коммерческом банке // Известия АлтГУ. - 2013. - № 2 (78). - С. 253-260.

10. Snell R. Moral foundations of the learning organization // Human Relations Volume. - 2007. - V. 54 (3). P. 19-30.

11. Жадько Н., Чуркина М. Управленческая эффективность руководителя. - М.: Альпина Паблишер, 2018. $-236 \mathrm{c}$.

12. Фонарев А.Р. Психология становления личности профессионала. - М.: Изд-во Московского психолого-социального института; Воронеж: НПО «МОДЭК», 2005. - 240 с.

13. Бёрчелл М., Робин Д. Отличная компания. Как стать работодателем мечты. - М.: Альпина Паблишер, 2013. $-272 \mathrm{c}$.

14. Андерсон К., Керри К. Менеджмент, ориентированный на потребителя. - М.: ФАИР-ПРЕСС, 2003. $288 \mathrm{c}$.

15. Морозова В.С. Понятие и структура предпринимательской компетентности менеджера // Ярославский педагогический вестник. - 2012. - № 2. - Т. 2. - С. 199-204.

16. Равен Д. Компетентность в современном обществе. - М.: Когито-Центр, 2002. - 396 с.

17. Ваулина Н.В., Бурдюгова О.В. Компетентностный подход к оценке персонала образовательной организации // International innovation research. Сб. ст. ХІІ Междунар. науч. практ. конф. - Пенза: Наука и Просвещение, 2018. - С. 218-225.

18. Андрющенко О.В. Лояльность в организации: теоретико-методологический аспект: автореф. дис. ... канд. социол. наук. - М., 2011. - 30 с.

19. Соломанидина Т.О. Организационная культура компании и лояльность персонала // Управление персоналом. - 2003. - № 5. - С. 54-56.

20. Даулинг Г. Репутация фирмы: создание, управление и оценка эффективности. - М.: ИМИДЖКонтакт: Инфра-М, 2003. - 368 с. 
21. Давлетова А.И. Эффективные черты лидерства в студенческих группах // Сборник научных трудов. Армавир: ИЦ АГПУ, 2004. - С. 36-43.

22. Утепбергенова 3.Д. Профессиональное саморазвитие педагога // Личность, семья и общество: вопросы педагогики и психологии. Сборник статей по материалам XVIII междунар. науч.-практ. конф. Ч. II. - Новосибирск: СибАК, 2012. - С. 71-76.

23. Svvailes S. Commitment to change. Profiles of commitment and in-role performance // Personnel Review. 2004. - V. 33. - № 2. - P. 187-204.

24. Медоуз Д. Азбука системного мышления. - М.: БИНОМ. Лаборатория знаний, 2015. - 343 с.

25. О'Коннор Дж. Искусство системного мышления: Необходимые знания о системах и творческом подходе к решению проблем. - М.: Альпина Бизнес Букс, 2006. - 256 с.

26. Пивонова Н.Е. Коммуникативная компетентность современной языковой личности. - СПб.: ИВЭСЭП, 2007. - $101 \mathrm{c}$.

27. Tresno G. Identifying the new influences in the Internet Era: Social Media and social Network Analysis // Journal of Product Innovation Management. - 2016. - V. 33. - Iss. 2. - P. 201-216.

28. Бирли У. Оценка 360 градусов. Стратегии, тактики и техники для воспитания лидеров. - М.: Эксмо, 2009. $-336 \mathrm{c}$.

29. Tyler T. R. Trust within organizations // Personnel Review. - 2003. - V. 32. - № 5. - P. 556-568.

30. Коптелов А.В., Обоскалов А.Г., Машуков А.В. Развитие профессиональной компетентности руководителей образовательных организаций средствами дополнительных профессиональных программ // Научно-методический электронный журнал «Концепт». - 2017. - Т. 31. - C. 811-815. URL: http://ekoncept.ru/2017/970177.htm (дата обращения 20.02.2019).

31. Чуланова О.Л. Компетентностный подход в работе с персоналом: теория, методология, практика. М.: Инфра-М, 2016. - 292 с.

32. Адизес И. Управление жизненным циклом корпорации. - СПб.: Питер, 2007. - 384 с.

Поступила 23.02.2019 2. 
UDC 005.95-057.177.2

\title{
EVALUATION OF ACTIVITIES OF THE ORGANIZATION LEADERS BASED ON THE COMPETENCE-ORIENTED MODEL
}

\author{
Konstantin I. Yantsen 1 , \\ yanzen14@gmail.com \\ Emma I. Meshcheryakova1, \\ mei22@mail.ru. \\ Anastasiya V. Larionova ${ }^{1}$, \\ vktusur@mail.ru \\ 1 National Research Tomsk State University, \\ 36, Lenin Avenue, Tomsk, 634050, Russia,
}

Konstantin I. Yantsen, Cand. Sc., associate professor, National Research Tomsk State University.

Emma I. Meshcheryakova, Dr. Sc., professor, National Research Tomsk State University.

Anastasiya V. Larionova, Cand. Sc., associate professor, National Research Tomsk State University.

Relevance of the research is determined by the need for creation of financial institutions capacity development in unstable social and economic situation in the world, which makes high demands to professional competence of the organizations managers. Subject of the research is the system of assessment of organization managers competency. The study supports competence-based model of the head. The authors based on the model of the Great Place to Work consider the experience of introducing competence in personnel management system of the organization necessary to achieve the objectives of the organization: corporate, professional, and universal. The aim of the study was to examine the effectiveness of functioning of the presented competence model in professional activities of the leaders of the Tomsk branch of the leading Russian Bank that allowed revealing the staff growth zones, selecting learning programmes, improving management system and getting feedback. The «360 degrees» method was used as the main research method, which allows you to get information on the employee's actions in real work situations and his/her personal and business qualities - competences.

The competence model can be used for the Bank personnel management system for full and effective use of the professional expertise of its staff. Competency-based assessment provides a number of opportunities for the company: the ability to develop uniform standards of performance, identify the strengths and weaknesses of each employee and use this information for his/her development. The study provides basic status indicators and the level of development of the competencies of managers of the Tomsk branch of the lead of Russian Bank. The competence model is presented as a reliable basis for efficient management of a bank personnel, as well as the method of its evaluation by the «360 degrees» method.

Key words: Bank, management, organization, skills, leadership, personnel, «360 degrees» methodology.

\section{REFERENCES}

1. Spenser-ml. L.M., Spenser S.M. Kompetentsii na rabote. Modeli maksimalnoy effektivnosti raboty [Competences at work. Maximum performance models]. Moscow, HIPPO Publ., 2005. 372 p.

2. Shinkevich O.K. Osnovy menedzhmenta: kurs lektsiy [Fundamentals of Management: Course of lectures]. Available at: http://uchebnik-online.com/soderzhanie/textbook_199.html (accessed 20 February 2018).

3. Khutorskoy A.V. Klyuchevye kompetentsii i obrazovatelnye standarty [Key competencies and educational standards]. Eydos. Available at: http://www.eidos.ru/journal/2002/0423.htm (accessed 20 February 2019). 
4. Zeer E.F. Psikhologiya professiy [Psychology of the professions]. Moscow, Akademicheskiy Proekt Publ., Ekaterinburg, Delovaya kniga Publ., 2003. 336 p.

5. Goncharova N.L. Kategoriya «kompetentnost» i «kompetentsiya» v sovremennoy obrazovatelnoy paradigme [The category of «competency» and «competence» in the modern educational paradigm]. Sbornik nauchnykh trudov SevKavGTU. Seriya «Gumanitarnye nauki», 2007, no. 5, pp. 13-16.

6. Zimnyaya I.A. Klyuchevye kompetentsii - novaya paradigma rezultata obrazovaniya [Key competencies new paradigm of the result of education]. Vysshee obrazovanie segodnya, 2003, no. 5, pp. 34-42.

7. Dokhoyan A.M. K voprosu o «kompetentsii» $\mathrm{i}$ "kompetentnosti» [On the issue of «competence» and «competency»]. Kontsept, 2015, vol. 26, pp. 11-15. Available at: http://e-koncept.ru/2015/95287.htm (accessed 20 February 2019).

8. Baydenko V.I., Oskarsson B. Bazovye navyki (klyuchevye kompetentsii) kak integriruyushchiy faktor obrazovatelnogo protsessa [Basic skills (key competencies) as an integrating factor of educational process]. Professionalnoe obrazovanie i formirovanie lichnosti spetsialista [Professional education and the formation of the personality of a specialist]. Available at: https://cyberleninka.ru/article/n/kompetentsii-vprofessionalnom-obrazovanii-k-osvoeniyu-kompetentnostnogo-podhoda (accessed 20 February 2019).

9. Dolzhenko R.A. Kompetentnostny podkhod kak osnova sistemy upravleniya personalom v kommercheskom banke [Competence-based approach as the basis of the personnel management system in a commercial bank]. Izvestiya AltGU, 2013, no. 2 (78), pp. 253-260.

10. Snell R. Moral foundations of the learning organization. Human Relations Volume, 2007, vol. 54 (3), pp. 19-30.

11. Zhadko N., Churkina M. Upravlencheskaya effektivnost rukovoditelya [Managerial efficiency]. Moscow, Alpina Publ., 2018. 236 p.

12. Fonarev A.R. Psikhologiya stanovleniya lichnosti professionala [Psychology of becoming a professional personality]. Moscow, Moscow Psychology and Social Institute Press; Voronezh, NPO «MODEK» Publ., 2005. 240 p.

13. Berchell M., Robin D. Otlichnaya kompaniya. Kak stat rabotodatelem mechty [Great company. How to become a dream employer]. Moscow, Alpina Publ., 2013. 272 p.

14. Anderson K., Kerri K. Menedzhment, orientirovanny na potrebitelya [Consumer oriented management]. Moscow, FAIR-PRESS Publ., 2003. 288 p.

15. Morozova V.S. Ponyatie i struktura predprinimatelskoy kompetentnosti menedzhera [The concept and structure of entrepreneurial competence manager]. Yaroslavskiy pedagogicheskiy vestnik, 2012, no. 2, vol. 2, pp. 199-204.

16. Raven D. Kompetentnost v sovremennom obshchestve [Competence in modern society]. Moscow, KogitoTsentr Publ., 2002. 396 p.

17. Vaulina N.V., Burdyugova O.V. Kompetentnostny podkhod k otsenke personala obrazovatelnoy organizatsii [Competence-based approach to evaluation of personnel of an educational organization]. International innovation research. Penza, Nauka i Prosveshchenie Publ., 2018. pp. 218-225.

18. Andryushchenko O.V. Loyalnost v organizatsii: teoretiko-metodologicheskiy aspekt. Avtoreferat Dis. Kand. nauk [Loyalty in the organization: theoretical and methodological aspect. Cand. Diss. Abstract]. Moscow, 2011. 30 p.

19. Solomanidina T.O. Organizatsionnaya kultura kompanii i loyalnost personala [Company organizational culture and staff loyalty]. Upravlenie personalom, 2003, no. 5, pp. 54-56.

20. Dauling G. Reputatsiya firmy: sozdanie, upravlenie i otsenka effektivnosti [Firm Reputation: Creation, Management, and Performance Evaluation]. Moscow, IMIDZh-Kontakt Publ., Infra-M Publ., 2003. 368 p.

21. Davletova A.I. Effektivnye cherty liderstva v studencheskikh gruppakh [Effective leadership features in student groups]. Sbornik nauchnykh trudov [Collection of scientific papers]. Armavir, AGPU Press, 2004. pp. $36-43$.

22. Utepbergenova Z.D. Professionalnoe samorazvitie pedagoga [Teacher professional self-development]. Lichnost, semya $i$ obshchestvo: voprosy pedagogiki $i$ psikhologii. Sbornik statey po materialam XVIII mezhdunarodnoy nauchno-prakticheskoy konferentsii. Ch. II [Collection of articles based on the materials of the XVIII international scientific-practical conference. P. II]. Novosibirsk, SibAK Publ., 2012, pp. 71-76.

23. Svvailes S. Commitment to change. Profiles of commitment and in-role performance. Personnel Review, 2004, vol. 33, no. 2, pp. 187-204.

24. Medouz D. Azbuka sistemnogo myshleniya [ABC of Systems Thinking]. Moscow, BINOM. Laboratoriya znaniy Publ., 2015. 343 p.

25. O'Konnor Dzh. Iskusstvo sistemnogo myshleniya: Neobkhodimye znaniya o sistemakh i tvorcheskom podkhode $k$ resheniyu problem [Art of Systems Thinking: Essential Knowledge of Systems and Creative Problem Solving]. Moscow, Alpina Biznes Buks, 2006. 256 p. 
26. Pivonova N.E. Kommunikativnaya kompetentnost sovremennoy yazykovoy lichnosti [Communicative competence of modern language personality]. St. Petersburg, IVESEP Publ., 2007. 101 p.

27. Tresno G. Identifying the new influences in the Internet Era: Social Media and social Network Analysis. Journal of Product Innovation Management, 2016, vol. 33, Iss. 2, pp. 201-216.

28. Birli U. Otsenka 360 gradusov. Strategii, taktiki i tekhniki dlya vospitaniya liderov [Evaluation of 360 degrees. Strategies, tactics and techniques for educating leaders]. Moscow, Eksmo Publ., 2009. 336 p.

29. Tyler T.R. Trust within organizations. Personnel Review, 2003, vol. 32, no. 5, pp. 556-568.

30. Koptelov A.V., Oboskalov A.G., Mashukov A.V. Razvitie professionalnoy kompetentnosti rukovoditeley obrazovatelnykh organizatsiy sredstvami dopolnitelnykh professionalnykh programm [Development of professional competence of heads of educational organizations by means of additional professional programs]. Kontsept, 2017, vol. 31, pp. 811-815. Available at: http://e-koncept.ru/2017/970177.htm (accessed 20 February 2019).

31. Chulanova O.L. Kompetentnostny podkhod $v$ rabote $s$ personalom: teoriya, metodologiya, praktika: monografiya [Competence approach to working with staff: theory, methodology, practice]. Moscow, InfraM Publ., 2016. 292 p.

32. Adizes I. Upravlenie zhiznennym tsiklom korporatsii [Corporate Lifecycle Management]. St. Petersburg, Piter Publ., 2007. 384 p.

Received: 23 February 2019. 